\title{
ros $R$, a Determinant of Nodulation Competitiveness in Rhizobium etli
}

\author{
Mark A. Bittinger, ${ }^{1}$ Jocelyn L. Milner, ${ }^{2}$ Barry J. Saville, ${ }^{3}$ and Jo Handelsman ${ }^{1,2}$ \\ ${ }^{1}$ Cellular and Molecular Biology Program, University of Wisconsin-Madison, Madison 53706 U.S.A.; \\ ${ }^{2}$ Department of Plant Pathology, University of Wisconsin-Madison, Madison 53706 U.S.A.; ${ }^{3}$ Department \\ of Botany, Erindale College, University of Toronto, Mississauga, Ontario L5L IC6 Canada \\ Received 8 August 1996. Accepted 13 November 1996.
}

We previously described a Tn5 mutant of Rhizobium etli strain CE3, designated CE3003, that is decreased in nodulation competitiveness, reduced in competitive growth in the rhizosphere, and has a hydrophobic cell surface (R. S. Araujo, E. A. Robleto, and J. Handelsman, Appl. Environ. Microbiol., 60:1430-1436, 1994). To determine the molecular basis for the mutant phenotypes, we identified a 1.2-kb fragment of DNA derived from the parent that restored the wild-type phenotypes to the mutant. DNA sequence analysis indicated that this $1.2-\mathrm{kb}$ fragment contained a single open reading frame that we designated ros $R$. The Tn5 insertion in CE3003 was within rosR. We constructed a derivative of CE3 that contained a deletion in $\operatorname{ros} R$, and this mutant was phenotypically indistinguishable from $\mathrm{CE} 3003$ in cell surface and competitive characteristics. Based on the nucleotide sequence, the deduced RosR amino acid sequence is $80 \%$ identical to that of the Ros protein from Agrobacterium tumefaciens and the MucR protein from Rhizobium meliloti. Both Ros and MucR are transcriptional repressors that contain a putative zinc-finger DNA-binding domain. This study defines a gene, $\operatorname{ros} R$, that is homologous to a family of transcriptional regulators and contributes to nodulation competitiveness of $\boldsymbol{R}$. etli. Moreover, we established that a single gene affects nodulation competitiveness, competitive growth in the rhizosphere, and cell surface hydrophobicity.

Microbial competition occurs in every environment that supports life. Microorganisms compete for space and nutrients with members of the same species and with members of other species. Identification of traits that contribute to microbial competitiveness will provide a better understanding of the interactions among organisms and may indicate selection pressures that drive evolution in a particular environment. Symbiotic nitrogen fixation provides an agriculturally important system in which to study microbial competitiveness. It is an ideal model system because the successful competitor occupies a plant organ, the root nodule, in essentially a pure cul-

Corresponding author: J. Handelsman; E-mail: joh@ @lantpath.wisc.edu

Nucleotide and/or amino acid sequence data are submitted to GenBank as accession number U61146. ture. It is also a system with significant applications. Nitrogen fixation by rhizobia in symbiotic association with legumes provides an environmentally sound alternative to nitrogen fertilizers for legumes and the crops grown in rotation with them, and reliable biological nitrogen fixation for production of certain crops is prevented by the lack of nodulation competitiveness of many Rhizobium strains used as inoculants. The result is that the inoculant strains do not occupy the host's nodules and no benefit is derived from inoculation (Graham 1981). Nodulation competitiveness is poorly understood and has been the focus of few mechanistic studies even though it is the single greatest barrier to extracting benefit for agriculture from biological nitrogen fixation. Understanding the molecular basis of nodulation competitiveness may lead to genetic or crop management strategies that will increase nodule occupancy by the inoculant strains.

Nodulation competitiveness is the relationship between the ratio of strains in the inoculum and the ratio of nodules occupied by those strains (Amarger and Lobreau 1982; Beattie et al. 1989). It is a quantitative phenotype, sometimes variable, and often requires large sample sizes to obtain reliable data. Recent work has demonstrated the power of molecular approaches in the study of competitiveness. Analyses of mutants defective in phenotypes that can be measured in culture have identified a number of important characteristics such as motility, antibiotic production, and EPS production (reviewed in Dowling and Broughton 1986; Streeter 1994; Triplett and Sadowsky 1992), which contribute to competitiveness.

CE3003, a Tn5-induced mutant with altered colony morphology derived from $R$. etli strain CE3, was previously isolated and characterized (Araujo et al. 1994). CE3003 produces domed colonies and is highly hydrophobic, whereas its parent produces flat colonies and is hydrophilic. CE3003 and CE3 grow at similar rates when they are grown separately in culture medium or inoculated singly onto bean plants. CE3003 nodulates bean plants and fixes nitrogen normally, and produces exopolysaccharide that is indistinguishable from that of CE3 by NMR analysis. However, CE3003 is greatly reduced in nodulation competitiveness and competitive growth in the rhizosphere compared with CE3 (Araujo et al. 1994), requiring a 17,000-fold excess of the mutant in the inoculum to achieve equal nodule occupancy by the mutant and the parent.

In this paper, we report the identification of a gene, $\operatorname{ros} R$, that restores parental phenotypes to mutant CE3003. Our analyses indicate that the original Tn5 mutation in CE3003 


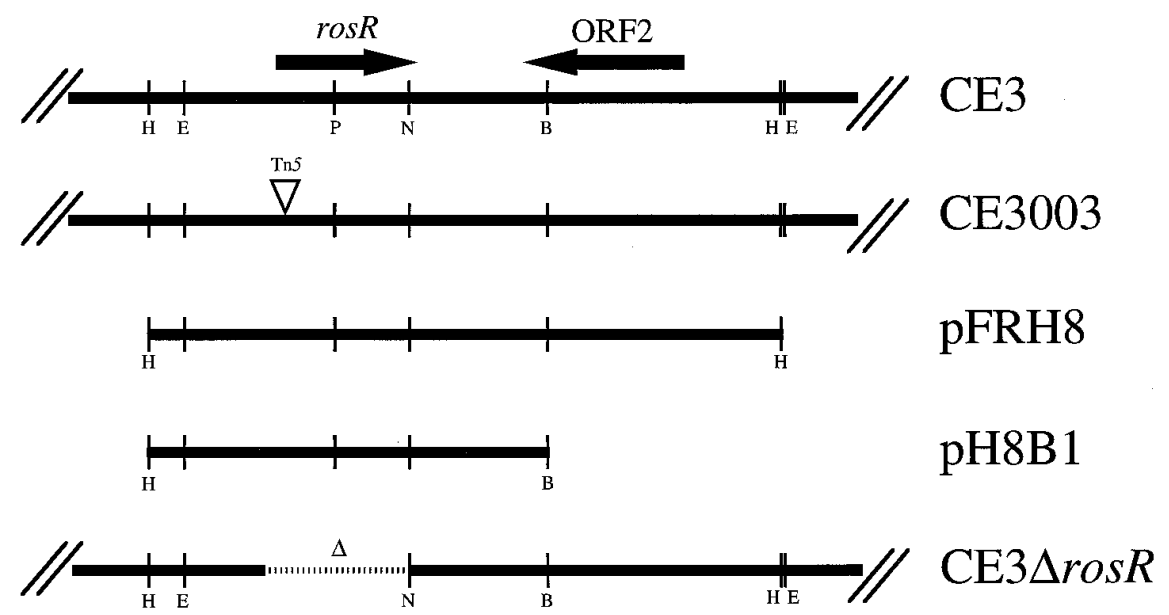

Fig. 1. Subcloning rosR from Rhizobium etli. The region surrounding the rosR gene in CE3 is diagrammed on the top line with the location of the ORF's indicated with arrows and the restriction sites indicated as vertical lines with the following letter designations: HindIII (H), EcoRI (E), PstI (P), NotI (N), and BamHI (B). Double slashes at ends of lines indicate additional genomic sequence. The position of the Tn5 insertion of CE3003 is indicated on the second line. The corresponding inserts of the restoring subclones, pFRH8 and pH8B1, are shown. The region that is deleted in CE3 the dashed line. DNA sequence from the HindIII site upstream of rosR to the EcoRI site downstream of rosR is deposited in Genbank, Accession no. U61146.

disrupts $\operatorname{ros} R$, and that $\operatorname{ros} R$ has a high degree of similarity to a family of transcriptional regulators.

\section{RESULTS}

Subcloning and sequence analysis of rosR.

We previously reported the isolation of a Tn5-induced mutant of $R$. etli strain CE3, designated CE3003, that was altered in colony morphology, growth in the rhizosphere in the presence of the parent, and nodulation competitiveness (Araujo et al. 1994). A recombinant cosmid, pRA3003, that contains cloned genomic DNA from CE3 was found to restore parental phenotypes to mutant CE3003 (Araujo et al. 1994). The objective of this work was to identify the region of the cosmid insert that affects these phenotypes.

Southern analysis of CE3003 revealed that the Tn5 insertion in CE3003 was within a 2-kb HindIII fragment. The corresponding 2-kb HindIII fragment of pRA3003 was identified and cloned into pLAFR3, producing pFRH8. Plasmid pFRH8 restored the parental colony morphology to CE3003.

We sequenced the 2-kb insert of pFRH8 (Genbank Accession no. U61146) and determined the size of the insert to be $1,927 \mathrm{bp}$. Analysis of the sequence, applying codon usage typical of Rhizobium spp., indicated two probable open reading frames (ORF's), one $432 \mathrm{bp}$ and one $456 \mathrm{bp}$ (Fig. 1). The entire $1,927 \mathrm{bp}$ of DNA sequence was submitted to a BLASTX (Altschul et al. 1990) search of sequence databases. This search translates the entire region in all six reading frames and compares the results to known protein sequences. Both ORF's had similarity to previous entries in the database.

The 432-bp ORF encoded a predicted protein of $15.7 \mathrm{kDa}$ that was $80 \%$ identical to Ros from Agrobacterium tumefaciens (Cooley et al. 1991), RosAR from A. radiobacter (Brightwell et al. 1995), and to MucR from Rhizobium meliloti (Keller et al. 1995) (Fig. 2). Because of the high degree of similarity, we designated this ORF as $\operatorname{ros} R$. A putative transcriptional terminator (Brendel and Trifonov 1984) was

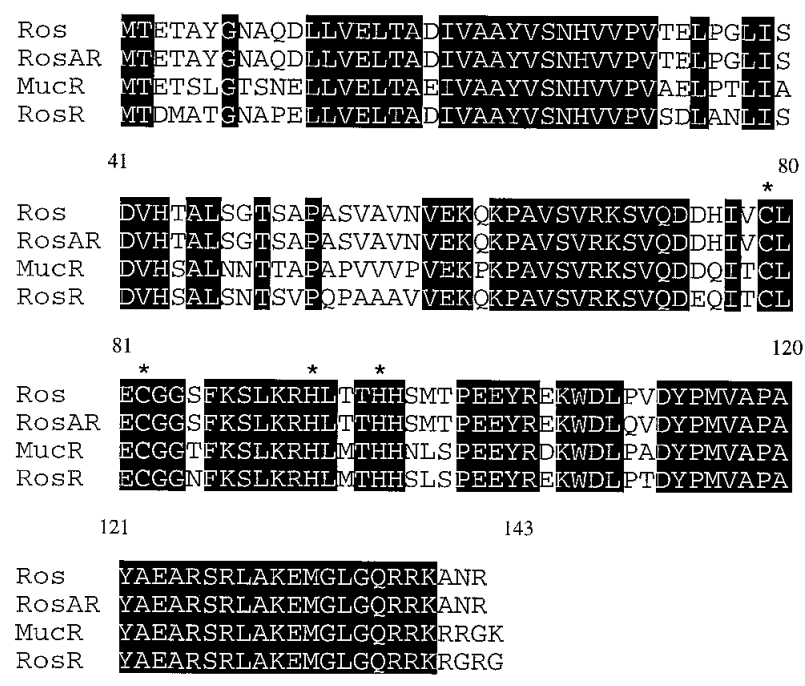

Fig. 2. Alignment of RosR homologues. Amino acid residues that are conserved in all four homologues are highlighted in black, and the residues believed to be important for the zinc-finger motif are indicated with an asterisk. Sequence data for Ros (Cooley et al. 1991), RosAR (Brightwell et al. 1995), and MucR (Keller et al. 1995) were reported previously.

located $20 \mathrm{bp}$ downstream of the rosR ORF, and a putative ribosome binding site (Ringquist et al. 1992) was centered 9 bp upstream of the rosR start codon. The second ORF downstream and convergently oriented to ros $R$ was designated ORF2 (Fig. 1). ORF2 was $69 \%$ identical to an ORF in the database, ORF4, which is adjacent and convergently oriented to the mucR gene in R. meliloti (data not shown; Keller et al. 1995).

To confirm that rosR was responsible for restoration of the parental colony morphology and other phenotypes described below, ORF2 was deleted from pFRH8 by removing a BamHI 
fragment, producing $\mathrm{pH} 8 \mathrm{~B} 1$. DNA sequence analysis indicated that $\mathrm{pH} 8 \mathrm{~B} 1$ contained an insert of 1,224 bp containing only the rosR ORF (Fig. 1). pH8B1 restored parental phenotypes to CE3003 (see below). Further evidence that rosR was responsible for these phenotypes was provided by the location of the Tn5 insertion in CE3003. DNA sequence analysis of pBSRT1, the plasmid containing the Tn5 cloned from CE3003, placed the transposon 20 bp downstream of the start codon of $\operatorname{ros} R$, within the $\operatorname{ros} R$ structural gene (Fig. 1).

\section{Site-directed mutations in $\operatorname{ros} R$.}

To determine whether the $\operatorname{Tn} 5$ mutation in $\operatorname{ros} R$ was solely responsible for the mutant phenotypes of CE3003, we constructed a derivative of CE3, CE3 $\Delta \operatorname{ros} R$, with a deletion spanning the rosR ORF on the chromosome (Fig. 1). CE3 3 ros $R$ was phenotypically indistinguishable from the Tn5-induced mutant CE3003 as it was reduced in nodulation competitiveness, growth in the rhizosphere (Fig. 3), and exhibited domed colony morphology.

In addition, a frameshift mutation was introduced into the cloned $\operatorname{ros} R$ by destroying an internal Pst I restriction site. The $1.2-\mathrm{kb}$ subclone with a frameshift in $\operatorname{ros} R$, designated $\mathrm{pH} 8 \mathrm{~B} 1 \Delta \mathrm{P} 2$, did not restore the parental colony morphology to the mutant $\mathrm{CE} 3003$. However, $\mathrm{pH} 8 \mathrm{~B} 1 \Delta \mathrm{P} 2$ appeared to be dominant or co-dominant in the wild type, CE3. Colonies of $\mathrm{CE} 3(\mathrm{pH} 8 \mathrm{~B} 1 \Delta \mathrm{P} 2)$ had a phenotype intermediate between the flat morphology of CE3 and the domed morphology of CE3003. Thus, the mutated rosR affected colony morphology when it was supplied on a plasmid in trans to a wild-type copy of $\operatorname{ros} R$. Such dominant phenotypes have also been observed with mutant $\operatorname{ros} A R$ alleles in $A$. radiobacter (Brightwell et al. 1995).

\section{Restoration of cell surface characteristics with rosR.}

$\mathrm{pH} 8 \mathrm{~B} 1$, the 1.2-kb subclone, restored the flat wild-type colony morphology to the mutant CE3003. CE3003(pH8B1) grown in YEM broth partitioned into the aqueous layer in the hexadecane partitioning assay, indicating that the parental cell surface characteristics were restored (data not shown). Without selection for the plasmid, cells lost $\mathrm{pH} 8 \mathrm{~B} 1$, as shown by loss of tetracycline resistance, and exhibited the domed colony morphology characteristic of CE3003.

\section{Restoration of competitive growth with $\operatorname{ros} R$.}

CE3 and CE3003 achieved similar populations in the rhizosphere at $96 \mathrm{~h}$ after inoculation when they were inoculated singly onto bean plants (data not shown). When the two strains were mixed in the inoculum at a 1:1 ratio, CE3 achieved sevenfold higher populations in the rhizosphere than CE3003 by $96 \mathrm{~h}$ after planting (Fig. 3). The ros $R$ subclone, pH8B1, restored the ability of CE3003 to grow competitively in the rhizosphere. Surprisingly, the representation of CE3003(pH8B1) in the rhizosphere was significantly higher (LSD, $\alpha=0.05$ ) than its representation in the inoculum when it was coinoculated with CE3, suggesting that the plasmid enhanced growth in the rhizosphere to levels greater than achieved by the wild type. Strain CE3013 was used as the competitor strain to assay competitive growth of CE3 and its derivatives that lack the $\operatorname{Tn} 5$ kanamycin-resistance gene. Strain CE3013 is a Tn5-marked derivative of CE3 that is indistinguishable from the parent strain in competitive growth in the rhizosphere and nodulation competitiveness (Beattie and Handelsman 1993). To examine the effect of multiple copies of $\operatorname{ros} R$ on the competitiveness of $\mathrm{CE} 3$, pH8B1 was mobilized into $\mathrm{CE} 3$. $\mathrm{CE} 3(\mathrm{pH} 8 \mathrm{~B} 1)$, was not significantly increased in its ability to grow competitively in the rhizosphere with CE3013. As with CE3003, the competitive growth of CE3 $\operatorname{rros} R$ was significantly increased by pH8B1. pLAFR3, the cloning vector, did not affect the competitive growth of CE3003, CE3, or CE3 3 ros $R$. These data indicate that the plasmid containing $\operatorname{ros} R$ restored competitive growth to the ros $R$ mutants.
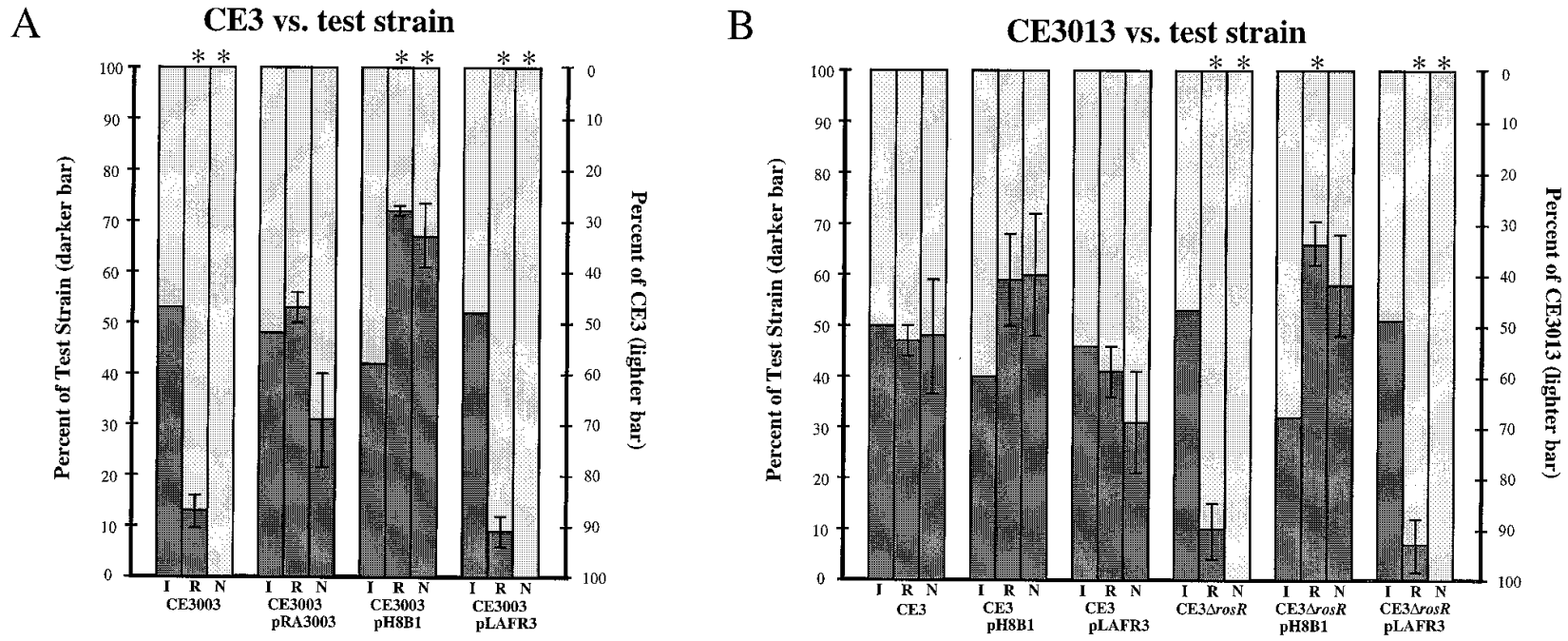

Fig. 3. Effect of $\operatorname{ros} R$ on competitive growth in the rhizosphere and nodulation competitiveness. These graphs report the percent of the strains in the inoculum (I), in the rhizosphere $96 \mathrm{~h}$ after planting (R), and in the nodules after 21 days (N). The lower, dark-colored segment of each bar represents the percent of each environment occupied by the test strain, which is named below the trio of bars. The upper, light-colored segment of each bar represents the percent of the reference strain, which in graph A is CE3, and in graph B is CE3013. A bar marked with an asterisk indicates that representation in the rhizosphere or nodules (indicated below bar) is significantly different from the representation of each strain in the inoculum by a protected LSD means separation test $(\alpha=0.05)$. Error bars indicate standard error. 


\section{Restoration of nodulation competitiveness with rosR.}

When beans were inoculated with CE3 and CE3003 in a 1:1 ratio, all of the nodules were occupied by CE3. The subclone containing rosR restored nodulation competitiveness to CE3003 and CE3 $\Delta$ ros $R$, significantly increasing their representation in the nodules (Fig. 3) (LSD, $\alpha=0.05$ ). pH8B1 did not significantly increase the nodulation competitiveness of CE3 when CE3(pH8B1) was coinoculated with CE3013. pLAFR3 alone did not affect competitiveness of any of the strains. These data indicate that $\operatorname{ros} R$ is sufficient to restore the wild-type phenotypes to the mutants, CE3003 and CE3 3 ros $R$.

\section{Phenotypes of CE3003 with ros in trans.}

Plasmid pCR8, carrying ros from A. tumefaciens (Cooley et al. 1991), was mobilized into CE3003 to determine if ros restored wild-type phenotypes to CE3003. CE3003(pCR8) exhibited colony morphology similar to CE3(pH8B1 $\Delta \mathrm{P} 2)$, which was an intermediate phenotype between that of CE3 and CE3003, and introduction of pCR8 did not restore nodulation competitiveness to CE3003 (data not shown). These data suggest that ros is unable to fully restore the wild-type phenotypes to the $\operatorname{ros} R$ mutant, although it affects the cell surface of CE3003 when placed in trans.

\section{DISCUSSION}

The goal of our work is to understand the genetic basis for competitiveness of bacteria on their plant hosts. Specifically, we applied a genetic analysis to understand nodulation competitiveness of $R$. etli, which has led to the identification of a gene, designated $\operatorname{ros} R$, that affects the cell surface, competitive growth in the rhizosphere, and nodulation competitiveness. A cloned copy of $\operatorname{ros} R$ restored the parental phenotypes to CE3003, a previously characterized mutant, and deletion of the ros $R$ gene from CE3 imparted phenotypes indistinguishable from those of CE3003. The ros $R$ gene encodes a predicted protein of $15.7 \mathrm{kDa}$ that has high sequence identity to Ros from A. tumefaciens (Cooley et al. 1991), RosAR from A. radiobacter (Brightwell et al. 1995), and MucR from $R$. meliloti (Keller et al. 1995). Despite the high degree of sequence similarity of RosR and the previously published homologues, there are dramatic functional differences between the genes.

$\operatorname{ros}, \operatorname{ros} A R$, and $m u c R$ all encode transcriptional repressors that bind to DNA in the promoter region of regulated genes. Members of this gene family have two characteristics in common: They affect EPS production and they contain a putative zinc-finger motif (Cooley et al. 1991; Brightwell et al. 1995; Keller et al. 1995; González et al. 1996). ros mutants do not produce EPS, while mucR mutants produce an alternative EPS. In contrast, although the ros $R$ mutant of $R$. etli tends to produce less recoverable EPS than the parent, the difference is not statistically significant, and the EPS produced by the ros $R$ mutant is structurally indistinguishable from that produced by the parent as determined by ${ }^{1} \mathrm{H}-\mathrm{NMR}$ spectroscopy (Araujo et al. 1994). Although $\operatorname{ros} R$ does not dramatically affect EPS production in $R$. etli, $\operatorname{ros} R$ is similar to the other members of this gene family in that it alters cell surface characteristics. $\operatorname{ros} R$ is functionally distinct in its role in defining the cell surface and competitiveness of CE3, since ros from A. tumefaci- ens did not restore these phenotypes to wild type in CE3003. These results suggest that the sequence differences among the homologues and the genetic environment in which they function are significant.

All of the previously reported $\operatorname{ros} R$ homologues are autoregulatory genes that have a binding site for the protein product in the promoter region of the structural gene. We have not identified the transcriptional start of the $\operatorname{ros} R$ gene; however, there appear to be no inverted repeats nor a consensus "Ros box" sequence (Keller et al. 1995) in the 600-bp region upstream of $\operatorname{ros} R$, suggesting that $\operatorname{ros} R$ may not be autoregulatory. The DNA sequence of the $\operatorname{ros} R$ region does not indicate another ORF upstream of $\operatorname{ros} R$; however, we do not have sufficient evidence to eliminate the possibility that $\operatorname{ros} R$ may be the last gene in a $\operatorname{ros} R$-regulated operon and that the promoter is located further upstream.

The high degree of similarity between RosR and this family of transcriptional regulators suggests that RosR may act as a transcriptional regulator in $R$. etli, and preliminary evidence supports this hypothesis. A protein of approximately $32 \mathrm{kDa}$ was observed in the inner membranes of CE3003 and not in CE3 (Araujo 1993). In addition, two-dimensional polyacrylamide gel electrophoresis of the cytosolic proteins revealed several differences between the protein patterns in CE3 and CE3003 (M. A. Bittinger and J. Handelsman, unpublished data).

If RosR is acting as a regulator of gene expression in $R$. etli, the decreased nodulation competitiveness phenotype observed in the ros $R$ mutant is probably the result of altered expression of one or more of the RosR-regulated genes. All of the phenotypes displayed by the $\operatorname{ros} R$ mutant may be due to altered expression of a single RosR-regulated gene or they may be due to independent RosR-regulated genes. Future studies will be directed toward identifying RosR-regulated genes and determining the subset of those genes that influence nodulation competitiveness and cell surface characteristics. Such experiments will enable us to determine the basis of the decreased competitiveness of the ros $R$ mutant. For example, we will determine whether the decreased competitiveness is due to the altered cell surface, or whether such phenotypes are due to separate, coregulated genes.

An intriguing aspect of this study was that the subclone containing rosR, $\mathrm{pH} 8 \mathrm{~B} 1$, not only restored competitive growth in the rhizosphere and nodulation competitiveness to CE3003 but also made CE3003 significantly more competitive than the parent strain (Fig. 3). Similarly, pH8B1 made CE3 $\Delta$ ros $R$ significantly more competitive than the test strain, CE3013, in its growth in the rhizosphere. pH8B 1 increased nodulation competitiveness of CE3 and CE3 3 ros $R$, but the effects were not statistically significant. Although some of the effects were not statistically significant, the effect of $\mathrm{pH} 8 \mathrm{~B} 1$ on competitive growth and nodulation competitiveness is striking and worthy of pursuit. These data may indicate that overexpression of ros $R$ enhances competitiveness, and future studies will quantitatively examine this effect.

Future studies of $\operatorname{ros} R$ will lead to a better understanding of bacterial characteristics that contribute to nodulation competitiveness and competitive growth in the rhizosphere. This knowledge may enhance our understanding of microbial competition and behavior of microorganisms in their environments and may lead to the development of rhizobial inoculants that are able to compete successfully with indigenous strains. 


\section{MATERIALS AND METHODS}

\section{Bacterial culture conditions.}

The bacterial strains and plasmids used in this study are listed in Table 1. Escherichia coli strains were grown on LB at $37^{\circ} \mathrm{C}$ (Sambrook et al. 1989). R. etli strains were grown on yeast extract-mannitol (YEM) (Vincent 1970) or tryptoneyeast extract (TY) (Beringer 1974) at $28^{\circ} \mathrm{C}$. All solid media contained $1.5 \%$ agar, and antibiotics were added at the following concentrations: ampicillin, $50 \mu \mathrm{g} / \mathrm{ml}$; tetracycline, 20 $\mu \mathrm{g} / \mathrm{ml}$; streptomycin, $200 \mu \mathrm{g} / \mathrm{ml}$; spectinomycin, $100 \mu \mathrm{g} / \mathrm{ml}$; gentamicin, $15 \mu \mathrm{g} / \mathrm{ml}$; nalidixic acid, $15 \mu \mathrm{g} / \mathrm{ml}$; chloramphenicol, $20 \mu \mathrm{g} / \mathrm{ml}$; and kanamycin, $25 \mu \mathrm{g} / \mathrm{ml}$ and $50 \mu \mathrm{g} / \mathrm{ml}$ for $E$. coli and $R$. etli, respectively. Sucrose was added to a final concentration of $5 \%$ in media for counter-selection of pJQ200KS and its derivatives (Quandt and Hynes 1993).

\section{Molecular techniques.}

Plasmid DNA was isolated from E. coli or $R$. etli by alkaline lysis (Sambrook et al. 1989) or using the Qiagen plasmid isolation kit (Qiagen Inc., Chatsworth, CA). Genomic DNA was isolated from $R$. etli by standard methods (Ausubel et al. 1994). Restriction and modification enzymes were used according to manufacturers' directions (Promega Corp., Madison, WI; New England Biolabs, Boston, MA; Gibco BRL, Richmond, CA). Plasmids were introduced into E. coli strain DH5 $\alpha$ by electroporation (Gene Pulser transfection apparatus, Bio-Rad Laboratories, Richmond, CA) and by calcium transformation (Sambrook et al. 1989), and into $R$. etli by triparental mating using the helper plasmid pRK2013 (Selvaraj and Iyer 1983). For Southern blot analyses, blotting, labeling of probes, and colorimetric detection of DNA was carried out with the Genius Kit (Boehringer Mannheim, Indianapolis, IN) on nylon membranes (Magna, MicroSeparatics Inc.) under conditions of high stringency. DNA fragments were purified from agarose gels with the Qiaex kit (Qiagen Inc.).

\section{Construction of $\operatorname{ros} R$ subclones.}

A 2-kb HindIII fragment of pRA3003, which corresponds to the site of the Tn5 insertion in CE3003, was gel purified and cloned into the HindIII site of pLAFR3, generating pFRH8. pH8B1 was constructed by deleting a $0.7-\mathrm{kb}$ BamHI fragment from $\mathrm{pFRH} 8$, which removed ORF2 from the subclone.

\section{DNA sequencing.}

$R$. etli DNA fragments cloned into pBSIIKS(+) and pLAFR3 were isolated from E. coli and used as templates for sequencing. Both strands of a 2-kb region of DNA were sequenced by primer walking. The forward and reverse M13/pUC primers were used to obtain the initial sequence. Subsequently, primers were designed based on the sequence of the insert and synthesized by the University of WisconsinMadison Biotechnology Center, Madison, WI. Sequencing reactions were performed with fluorescent dye-labeled dideoxy terminators using the PRIZM cycle sequencing kit (Applied Biosystems Inc., Foster City, CA). Sequencing reaction products were separated and detected at the University of WisconsinMadison Biotechnology Center on an ABI fluorescent sequencer. The partial DNA sequences were aligned and compiled, open reading frames identified, and codon usage analyzed with SeqMan and SeqEdit software (DNASTAR Inc., Madison, WI) and Codon Use 3.3 (Conrad Halling, University of Chicago). DNA and protein comparisons were carried out with the BLAST algorithms (Altschul et al. 1990) via the NCBI BLAST E-mail server and the GCG Wisconsin Sequence Analysis Software Package (Genetics Computer Group Inc.).

Table 1. Bacterial strains and plasmids used in this study

\begin{tabular}{|c|c|c|}
\hline Strain or plasmid & Description $^{a}$ & Reference \\
\hline \multicolumn{3}{|l|}{ Strains } \\
\hline R. etli CE3 & Spontaneous $\mathrm{Sm}^{\mathrm{r}}$ mutant of CFN42, $\mathrm{Nx}^{\mathrm{r}} \mathrm{Sm}^{\mathrm{r}}$ & Noel et al. 1984 \\
\hline R. etli CE3003 & $\operatorname{ros} R:: \operatorname{Tn} 5, \mathrm{Nx}^{\mathrm{r}} \mathrm{Sm}^{\mathrm{r}} \mathrm{Km}^{\mathrm{r}}$ & Araujo et al. 1994 \\
\hline R. etli CE3013 & $\begin{array}{l}\text { Tn } 5 \text { derivative of CE3 unaffected in competitive growth in the rhizosphere and } \\
\text { nodulation competitiveness, } \mathrm{Nx}^{\mathrm{r}} \mathrm{Sm}^{\mathrm{r}} \mathrm{Km}^{\mathrm{r}}\end{array}$ & Beattie and Handelsman 1993 \\
\hline R. etli CE3 3 rosR & CE3 derivative with $\operatorname{ros} R$ deleted, $\mathrm{Nx}^{\mathrm{r}} \mathrm{Sm}^{\mathrm{r}}$ & This study \\
\hline E. coli $\mathrm{DH} 5 \alpha$ & $\begin{array}{l}\phi 80 \mathrm{~d} l a c Z \Delta \mathrm{M} 15 \Delta(\text { lacZYA-argF }) \mathrm{U} 169 \text { recAl endA1 gyrA96 thi-1 hsdR17 supE44 } \\
\quad \text { relA1 deoR }\end{array}$ & Hanahan 1983 \\
\hline \multicolumn{3}{|c|}{ 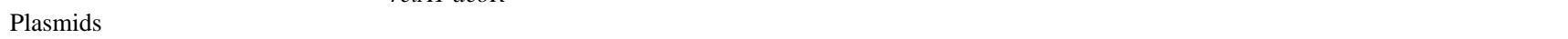 } \\
\hline pGEM11Zf(+) & Cloning and sequencing vector, $\mathrm{Ap}^{\mathrm{r}}$ & Promega Corp. \\
\hline pBSIIKS $(+) / \mathrm{SK}(+)$ & Cloning and sequencing vector, $\mathrm{Ap}^{\mathrm{r}}$ & Stratagene \\
\hline pJQ200KS & Mobilizable suicide vector, $s a c B, \mathrm{Gm}^{\mathrm{r}}$ & Quandt and Hynes 1993 \\
\hline pSUP202 & Mobilizable suicide vector, $\mathrm{Ap}^{\mathrm{r}} \mathrm{Cm}^{\mathrm{r}} \mathrm{Tc}^{\mathrm{r}}$ & Simon et al. 1983 \\
\hline pRA3003 & Cosmid containing $\operatorname{ros} R, \mathrm{Tc}^{\mathrm{r}}$ & Araujo et al. 1994 \\
\hline pLAFR3 & Broad host range cosmid cloning vector, $\mathrm{Tc}^{\mathrm{r}}$ & Staskawicz et al. 1987 \\
\hline pRK2013 & $\mathrm{Tra}^{+}$helper plasmid, $\mathrm{Km}^{\mathrm{r}}$ & Figurski et al. 1979 \\
\hline pCR8 & ros subclone, $\mathrm{Sp}^{\mathrm{r}}$ & Cooley et al. 1991 \\
\hline pFRH8 & 2-kb $\operatorname{ros} R$ subclone in pLAFR3, $\mathrm{Tc}^{\mathrm{r}}$ & This study \\
\hline $\mathrm{pH} 8 \mathrm{~B} 1$ & $1.2-\mathrm{kb}$ ros $R$ subclone in pLAFR3, $\mathrm{Tc}^{\mathrm{r}}$ & This study \\
\hline $\mathrm{pH} 8 \mathrm{~B} 1 \Delta \mathrm{P} 2$ & $\mathrm{pH} 8 \mathrm{~B} 1$ with 4-bp deletion in $\operatorname{ros} R, \mathrm{Tc}^{\mathrm{r}}$ & This study \\
\hline pGMUPS & pGEM11Zf(+) with 580-bp upstream fragment, $\mathrm{Ap}^{\mathrm{r}}$ & This study \\
\hline pBSR1 & pBSIIKS(+) with 1.8 subclone of $\operatorname{ros} R, \mathrm{Ap}^{\mathrm{r}}$ & This study \\
\hline pBSRT1 & pBSIISK(+) with EcoRI fragment containing $\operatorname{ros} R:: \operatorname{Tn} 5$ from CE3003 & This study \\
\hline pBSR $1 \Delta \mathrm{N} 1$ & pBSRI with fragment downstream of $\operatorname{ros} R, \mathrm{Ap}^{\mathrm{r}}$ & This study \\
\hline $\mathrm{pBS} \Delta \operatorname{ros} R$ & pBSR $1 \Delta \mathrm{N} 1$ with deletion spanning $\operatorname{ros} R, \mathrm{Ap}^{\mathrm{r}}$ & This study \\
\hline pSUP $\triangle \operatorname{ros} R$ & pSUP202 with $\operatorname{ros} R$ deletion, $\mathrm{Tc}^{\mathrm{r}} \mathrm{Cm}^{\mathrm{r}}$ & This study \\
\hline $\mathrm{pJQ} \Delta \operatorname{ros} R$ & pJQ200KS with $\operatorname{ros} R$ deletion, $\mathrm{Gm}^{\mathrm{r}}$ & This study \\
\hline
\end{tabular}

a Antibiotic resistances are abbreviated as follows: ampicillin (Ap), chloramphenicol $(\mathrm{Cm})$, gentamicin $(\mathrm{Gm})$, kanamycin $(\mathrm{Km})$, streptomycin $(\mathrm{Sm})$, spectinomycin $(\mathrm{Sm})$, and tetracycline $(\mathrm{Tc})$. 


\section{Localization of $\operatorname{Tn} 5$.}

Genomic DNA from CE3003 was digested with EcoRI, an enzyme that does not cut within the Tn5, and this DNA was ligated into the EcoRI site of pBSIISK(+), to create pBSRT1. E. coli transformants that were both kanamycin and ampicillin resistant (the resistances conferred by $\operatorname{Tn} 5$ and the plasmid, respectively) were isolated. Primers that were designed for sequencing the insert of pFRH8 were used to sequence into the transposon on pBSRT1.

\section{Construction of a ros $R$ deletion strain.}

A deletion of $\operatorname{ros} R$ was accomplished by fusing regions upstream and downstream of $\operatorname{ros} R$ and using a counter-selectable suicide vector for marker exchange. The 1.8-kb EcoRI fragment that encompassed the rosR ORF was cloned into pBSIIKS(+), producing pBSR1. One end of the insert of pBSR1 was eliminated by deleting a NotI fragment. This produced a construct, pBSR $1 \Delta \mathrm{N} 1$, with all but the last 11 bp of $\operatorname{ros} R$ deleted, containing 1.14-kb of DNA from the region downstream of $\operatorname{ros} R$.

Additional DNA sequence of the region upstream of $\operatorname{ros} R$ was obtained by sequencing one strand of pRA3003 by primer walking. This sequence (not deposited) was used to design a primer $\triangle \mathrm{RF}, 5^{\prime}$-CCAATCATGCCGGTTTGACG-3', to PCRamplify 580 bp of upstream DNA (from 593 bp to 12 bp upstream of the rosR ORF) in combination with primer $\Delta \mathrm{RR}$, 5'GTTAGCATGCTCAAACGATC-3', using Pfu polymerase. This PCR product was cloned into the blunt HincII site of pGEM11Zf(+) producing pGMUPS. This upstream fragment was excised from pGMUPS using SacI and NotI vector sites on each side of the insert.

pBSR1 $1 \Delta$ N1 was digested with SacI and NotI and the SacINotI upstream fragment from pGMUPS was inserted into pBSR $1 \Delta \mathrm{N} 1$, yielding $\mathrm{pBS} \Delta \operatorname{ros} R$. PvuII sites in the vector were cleaved to excise a blunt $2.2-\mathrm{kb}$ fragment containing the fused upstream and downstream sequences. PstI linkers (Promega) were ligated onto this fragment and cut with PstI to create sticky ends. This PstI fragment with the rosR deletion was then inserted into the PstI site of pSUP202, producing pSUP $\Delta$ rosR. The Pst I fragment with rosR deleted was removed from pSUP $\Delta$ rosR and inserted into the PstI site of pJQ200KS a counter-selectable suicide vector, yielding pJQ $\Delta$ rosR. This construct was mobilized into CE3 and single crossover integrants were isolated on YEM containing gentamicin, streptomycin, and nalidixic acid. A single integrant was chosen and grown in YEM broth without gentamicin and then plated on YEM with streptomycin, nalidixic acid, and sucrose, a medium that is toxic to bacteria with a functional $s a c B$ gene. Approximately $5 \%$ of the colonies that grew on this medium had the domed colony morphology characteristic of CE3003 and were no longer resistant to gentamicin. Southern analysis of one of the domed derivatives using the $1.8-\mathrm{kb}$ $E c o$ RI fragment as a probe, indicated a deletion in the $r o s R$ region. This strain was designated CE $3 \Delta \operatorname{ros} R$.

\section{Construction of a frameshift mutation in $\operatorname{ros} R$.}

The unique PstI site within $\operatorname{ros} R$ is $190 \mathrm{bp}$ from the $5^{\prime}$ end of the rosR ORF (Fig. 1). pH8B1 was cut with PstI, blunted with the exonuclease activity of $\mathrm{T} 4$ polymerase, and religated, yielding $\mathrm{pH} 8 \mathrm{~B} 1 \Delta \mathrm{P} 2$. Sequence analysis of $\mathrm{pH} 8 \mathrm{~B} 1 \Delta \mathrm{P} 2$ confirmed that $4 \mathrm{bp}$ were deleted. This 4 -bp deletion created a frameshift in the ros $R$ ORF, and is predicted to cause incorporation of 28 missense residues after the 64th amino acid residue.

\section{Phenotypic assays.}

Colony morphology of the rosR mutants was observed on YEM plates (Araujo et al. 1994). Hydrophobicity was assessed by the hexadecane separation method (Rosenberg et al. 1980). YEM broth cultures of $\operatorname{ros} R$ strains were mixed 1:1 with hexadecane and agitated vigorously with a vortex mixer at the maximum setting for $1 \mathrm{~min}$ and allowed to separate for $1 \mathrm{~h}$ at room temperature. The turbidity of the resulting aqueous and organic layers was then observed visually (Araujo et al. 1994; Rosenberg et al. 1980).

Competitive growth in the rhizosphere was measured as described previously (Araujo et al. 1994). Briefly, bacterial cells were scraped off TY plates with appropriate antibiotics and resuspended in sterile water and diluted to approximately $10^{5}$ cells $/ \mathrm{ml}$. From these dilutions, mixtures of strains were made in a 1:1 ratio. Dilution plating of inocula was then conducted to determine cell numbers. Phaseolus vulgaris cultivar Puebla 152, provided by Kenneth A. Kmiecik, Dept. of Horticulture, University of Wisconsin-Madison, was used in all plant experiments. Seeds were surface disinfected by treatment with $95 \%$ ethanol for $30 \mathrm{~s}$ and $1.6 \%$ sodium hypochlorite for $3 \mathrm{~min}$, and planted in a sterile sand and vermiculite mixture (1.5:1 $\mathrm{vol} / \mathrm{vol})$ in glass tubes. Four bean plants were used for each treatment. One milliliter of inoculum was added to each tube, and the tubes were placed in a growth chamber at $24^{\circ} \mathrm{C}$ with a 12-h photoperiod with a light intensity of 244 microeinsteins $/ \mathrm{m}^{2} / \mathrm{s}$. Each seedling was recovered at $96 \mathrm{~h}$ after inoculation, placed in $9 \mathrm{ml}$ of sterile distilled water, and sonicated in a model 2200 ultrasonic bath (Branson Ultrasonics Corp., Danbury, CT) for $30 \mathrm{~s}$. The resulting suspension was serially diluted and plated on YEM with appropriate antibiotics to distinguish strains, and the bacterial populations in the rhizosphere were calculated.

Assays for nodulation competitiveness were conducted as previously described (Araujo et al. 1994). Briefly, bacteria were grown on TY plates with appropriate antibiotics. The cells were scraped off plates, resuspended in sterile water and diluted to an $A_{600}$ of 0.1 (approximately $10^{8}$ cells per ml). Inocula were prepared by mixing these dilutions in 1:1 ratios. Cell suspensions were dilution plated on YEM with appropriate antibiotics to determine cell numbers. One milliliter of inoculum was applied to the planted surface-disinfected seed. Bean plants were grown in the growth chamber and watered with sterile nitrogen-free plant nutrient solution as needed for 21 days. Six plants were used in each treatment, and eight nodules were harvested from each plant. Root nodules were removed from plants and the strains in the nodules were identified by streptomycin and kanamycin resistance (Beattie et al. 1989). Nodules harboring streptomycin-resistant, kanamycin-sensitive bacteria were typed as either CE3 (or its plasmid derivatives) or CE3 $\Delta$ ros $R$ (or its plasmid derivatives). Nodules harboring streptomycin-resistant, kanamycin-resistant bacteria were typed as either CE3003 (or its plasmid derivatives) or CE3013. Double occupancy of nodules by both competitor strains cannot be assessed accurately with this assay since only one of the competitors has a unique antibiotic resistance; however, previous studies have shown that only a minority of $P$. vulgaris nodules are doubly occupied (Araujo et al. 1994; Beattie et al. 1989). 


\section{ACKNOWLEDGMENTS}

We thank Sandra J. Raffel for assisting with the plant experiments, Scott B. Bintrim and Eric V. Stabb for critically reviewing the manuscript, Alberto I. Roca for assisting in preparation of the figures, and Laurie Luther for assisting in preparation of the manuscript. This work was supported by USDA CRGO Grant \#93373059236 and a Hatch project from the College of Agricultural and Life Sciences, University of Wisconsin-Madison.

\section{LITERATURE CITED}

Altschul, S. F., Gish, W., Miller, W., Myers, E. W., and Lipman, D. J. 1990. Basic local alignment search tool. J. Mol. Biol. 215:403-410.

Araujo, R. S. 1993. Mutational analysis of the cell surface and nodulation competitiveness of Rhizobium leguminosarum biovar phaseoli. $\mathrm{Ph}$.D. dissertation. University of Wisconsin-Madison, Madison, WI.

Araujo, R. S., Robleto, E. A., and Handelsman, J. 1994. A hydrophobic mutant of Rhizobium etli altered in nodulation competitiveness and growth in the rhizosphere. Appl. Environ. Microbiol. 60:1430-1436.

Amarger, N., and Lobreau, J. P. 1982. Quantitative study of nodulation competitiveness in Rhizobium strains. Appl. Environ. Microbiol. 44:583-588.

Ausubel, F. M., Brent, R., Kingston, R. E., Moore, D. D., Smith, J. A., Seidman, J. G., and Struhl, K., eds. 1994. Pages 2.4.1-2.4.5 in: Current Protocols in Molecular Biology. John Wiley \& Sons, Inc., New York

Beattie, G. A., Clayton, M. K., and Handelsman, J. 1989. Quantitative comparison of the laboratory and field competitiveness of Rhizobium leguminosarum biovar phaseoli. Appl. Environ. Microbiol. 55:27552761.

Beattie, G. A., and Handelsman, J. 1989. A rapid method for the isolation and identification of Rhizobium from root nodules. Microbiol. Methods 9:29-33.

Beattie, G. A., and Handelsman, J. 1993. Evaluation of a strategy for identifying nodulation competitiveness genes in Rhizobium leguminosarum biovar phaseoli. J. Gen. Microbiol. 139:529-538.

Berg, J. M. 1990. Zinc finger domains: Hypotheses and current knowledge. Annu. Rev. Biophys. Chem. 19:405-421.

Beringer, J. E. 1974. R-factor transfer in Rhizobium leguminosarum. J. Gen. Microbiol. 84:188-198.

Brendel, V., and Trifonov, E. N. 1984. A computer algorithm for testing potential prokaryotic terminators. Nucleic Acids Res. 12:4411-4427.

Brightwell, G., Hussain, H., Tiburtius, A., Yeoman, K. H., and Johnston, A. W. B. 1995. Pleiotropic effects of regulatory ros mutants of Agrobacterium radiobacter and their interaction with $\mathrm{Fe}$ and glucose. Mol. Plant-Microbe Interact. 8:747-754.

Cooley, M. B., D'Souza, M. R., and Kado, C. I. 1991. The virC and virD operons of the Agrobacterium Ti plasmid are regulated by the ros chromosomal gene: Analysis of the cloned ros gene. J. Bacteriol. 173:2608-2616.

Dowling, D. N., and Broughton, W. J. 1986. Competition for nodulation of legumes. Annu. Rev. Microbiol. 40:131-157.

D’Souza-Ault, M. R., Cooley, M. B., and Kado, C. I. 1993. Analysis of the Ros repressor of Agrobacterium virC and virD operons: Molecular intercommunication between plasmid and chromosomal genes. J. Bacteriol. 175:3486-3490.

Figurski, D. H., and Helinski, D. R. 1979. Replication of an origincontaining derivative of plasmid RK2 dependent on a plasmid function provided in trans. Proc. Natl. Acad. Sci. USA 76:1648-1652.

González, J. E., Reuhs, B. L., and Walker, G. C. 1996. Low molecular weight EPS II of Rhizobium meliloti allows nodule invasion in Medicago sativa. Proc. Natl. Acad. Sci. USA 93:8636-8641.

Graham, P. H. 1981. Some problems of nodulation and symbiotic nitrogen fixation in Phaseolus vulgaris L.: A review. Field Crops Res. 4:93-112.

Hanahan, D. 1983. Studies on transformation of Escherichia coli with plasmids. J. Mol. Biol. 166:557-580.

Keller, M., Roxlau, A., Weng, W. M., Schmidt, M., Quandt, J., Niehaus, K., Jording, D., Arnold, W., and Pühler, A. 1995. Molecular analysis of the Rhizobium meliloti mucR gene regulating the biosynthesis of the exopolysaccharides succinoglycan and galactoglucan. Mol. PlantMicrobe Interact. 8:267-277.

Noel, K. D., Sanchez, A., Fernandez, L., Leemans, J., and Cevallos, M. A. 1984. Rhizobium phaseoli symbiotic mutants with transposon $\mathrm{Tn} 5$ insertions. J. Bacteriol. 158:148-155.

Quandt, J., and Hynes, M. F. 1993. Versatile suicide vectors which allow direct selection for gene replacement in Gram-negative bacteria. Gene 127:15-21.

Ringquist, S., Shinedling, S., Barrick, D., Green, L., Binkley, J., Stormo, G. D., and Gold, L. 1992. Translation initiation in Escherichia coli: Sequences within the ribosome-binding site. Mol. Microbiol. 6:12191229.

Rosenberg, M., Gutnick, D., and Rosenberg, E. 1980. Adherence of bacteria to hydrocarbons: A simple method for measuring cell-surface hydrophobicity. FEMS Microbiol. Lett. 9:29-33.

Sambrook, J., Fritsch, E. F., and Maniatis, T. 1989. Molecular Cloning: A Laboratory Manual. Cold Spring Harbor Laboratory, Cold Spring Harbor, NY.

Selvaraj, G., and Iyer, V. N. 1983. Suicide plasmid vehicles for insertion mutagenesis in Rhizobium meliloti and related bacteria. J. Bacteriol. 156:1292-1300.

Simon, R., Priefer, U., and Pühler, A. 1983. A broad host range mobilization system for in vivo genetic engineering: Transposon mutagenesis in gram negative bacteria. Biotechnology 1:784-791.

Staskawicz, B., Dahlbeck, D., Keen, N., and Napoli, C. 1987. Molecular characterization of cloned avirulence genes from race 0 and race 1 of Pseudomonas syringae pv. glycinea. J. Bacteriol. 169:5789-5794.

Streeter, J. G. 1994. Failure of inoculant rhizobia to overcome the dominance of indigenous strains for nodule formation. Can. J. Microbiol. 40:513-522.

Triplett, E. W., and Sadowsky, M. J. 1992. Genetics of competition for nodulation of legumes. Annu. Rev. Microbiol. 46:399-428.

Vincent, J. M. 1970. A Manual for the Practical Study of the Root Nodule Bacteria. IBP Handbook No. 15. Blackwell Scientific Publications Ltd., Oxford.

Zhan, H., Levery, S. B., Lee, C. C., and Leigh, J. A. 1989. A second exopolysaccharide of Rhizobium meliloti strain SU47 that can function in root nodule invasion. Proc. Natl. Acad. Sci. USA 86:3055-3059. 